\title{
Effect of exposure to formaldehyde on the skin of first-year medical students during Anatomy dissection: A longitudinal study
}

\author{
Dipak Kumar Dhar', Sudeepa Chaudhuri², Sumit Kumar Singh ${ }^{3}$, Sudip Bhattacharya ${ }^{4, *}$ \\ ${ }^{1}$ Tutor, ${ }^{2}$ Professor and Head, ${ }^{3}$ PG Student, ${ }^{4}$ Assistant Professor, ${ }^{1,2}$ Dept. of Physiology, ${ }^{3,4}$ Dept. of Community Medicine, ${ }^{1,3,4}$ Himalayan \\ Institute of Medical Sciences, Dehradun, Uttarakhand, ${ }^{2}$ Rohilkhand Medical College and Hospital, Bareilly, Uttar Pradesh, India
}

*Corresponding Author: Sudip Bhattacharya

Email: drsudip81@gmail.com

\begin{abstract}
Exposure to formaldehyde is one of the various occupational hazards experienced by a doctor. It is used in its aqueous form, formalin for embalming cadavers which are used for teaching gross anatomy by dissection. Therefore, medical students in their first year routinely handle the cadaver and dermal contact is thus a significant and consistent portal of exposure to formaldehyde. The toxic and allergic potential of formaldehyde is well documented in research literature. The present study was intended to assess the various dermatological manifestations of this exposure and provide a possible understanding of the mechanism behind it by estimation of eosinophil count. Descriptive statistics, Friedman's Test and paired-t test were used for statistical analysis. A p-value $<0.05$ was considered significant. The study revealed that dermal symptoms persist late and start to decline by six months onwards. A rise in absolute eosinophil count was also noted. The study highlights the role of formaldehyde as an occupational hazard and suggests a possible allergic mechanism behind these symptoms. Therefore, we should encourage use of protective gloves and other options available to reduce exposure.
\end{abstract}

Keywords: Formaldehyde, Medical students, Dermal symptoms, Skin reactions.

\section{Introduction}

Health and well-being have always been the fulcrum of human civilization. Therefore, the role of a doctor in the society is of pivotal importance. However, a budding doctor in the course of his medical education and training is exposed to various occupational hazards. One of these impediments is the exposure to formaldehyde that occurs during gross anatomy dissection in the first year.

Formaldehyde (HCHO) is an aldehyde produced by the oxidation of methyl alcohol. At room temperature, it exists as a gas which has noxious and irritating properties. Formalin is $37 \%$ aqueous solution of formaldehyde. ${ }^{1}$ In the field of medical science, formalin has got numerous uses ranging from sterilization of instruments to preservation of biological specimens and embalming of cadavers. However, studies show that formaldehyde can be toxic and allergenic and even has carcinogenic potential. ${ }^{2,3}$ There is substantial evidence in the research literature today about the effect of formalin on human physiology manifesting as various mucosal irritation symptoms, effects on lung functions and dermatitis. ${ }^{4-6}$ Skin problems like eczema and skin irritation start appearing when the levels of formaldehyde in ambient environment exceed 2 ppm. ${ }^{5}$

Study of human cadaver is a time-tested method of learning anatomy. In fact, dissection of human cadaver is the first interface where a medical student gets to appreciate the three-dimensional structure of the human body by visual and tactile pathways and reinforce what he learns in theory. These experiences cannot be reproduced or extrapolated on computerized models. Even with the best of modern teaching technology at disposal, the classical method of cadaver-based learning cannot be replaced or paralleled. ${ }^{7}$ Therefore, instructors and students routinely handle the cadaver. As, these cadavers are embalmed with formalin, there is a consistent exposure to formaldehyde during the entire first year. Direct contact with skin is one of the main portals of exposure. Studies available in literature which assess the development of various skin reactions longitudinally are very limited. The present study aimed at evaluating dermatological symptoms experienced by medical students after exposure to formaldehyde and how their occurence changed over the first year. It was also intended to provide an insight into the possible mechanism behind these reactions by estimating the absolute eosinophil count.

\section{Materials and Methods}

A longitudinal, descriptive study was conducted in the Department of Physiology, Rohilkhand Medical College and Hospital among first year MBBS students in the academic year 2015-16. Approval was obtained from the Institutional Ethics Committee (vide document IEC/IRB No. IEC/27/2015). Students having no history of previous exposure to formalin by inhalational route or direct contact were considered as subjects. The exclusion criteria included presence of any pre-existing acute or chronic inflammatory dermatological disorders, allergic dermatitis, known history of food, drug or chemical hypersensitivity and any mucosal irritation symptoms. Students those who were not willing to participate were also excluded from the study. Eighty (80) medical students who suitably fulfilled these criteria were selected using simple random sampling technique. Informed consent was taken from every participant after explaining the nature of the study. Various skin symptoms experienced by the students were recorded on a pre-designed structured questionnaire. The questions also had a provision for subjective grading of increasing level of discomfort of a particular symptom into absent, mild, moderate and severe intensities. The first recording done within 24 hours of first exposure to formalin served as the baseline and it was followed-up at the end of $1^{\text {st }}, 6^{\text {th }}$ and $10^{\text {th }}$ month for 
longitudinal assessment. Descriptive statistics and suitable statistical tests like Friedman's test were applied. Absolute Eosinophil count was calculated from the differential leucocyte count and total leucocyte count of the students which were recorded as per standard procedure. ${ }^{8,9}$ Paired ' $t$ ' test was used to ascertain the statistical significance of eosinophil count recorded at the beginning (baseline) and end of the academic year. A p-value $<0.05$ was considered statistically significant.

\section{Results and Observations}

The skin symptoms experienced by the students included itching and redness and eruptions (like blisters \& exfoliation or peeling of skin, etc) in hands. Their occurrence has been shown in Table 1. After applying Friedman's test, the pattern of change in these symptoms was found to be statistically significant.

Table 1: Pattern of change in skin symptoms

\begin{tabular}{|c|c|c|c|c|c|c|}
\hline \multirow{2}{*}{$\begin{array}{l}\text { Time of } \\
\text { recording }\end{array}$} & \multicolumn{3}{|l|}{ Present } & \multirow[b]{2}{*}{ Absent } & \multirow[b]{2}{*}{ Total } & \multirow[t]{2}{*}{ P-value } \\
\hline & Mild & Moderate & Severe & & & \\
\hline \multicolumn{7}{|c|}{ Experience of itching } \\
\hline Baseline & 12 & 2 & 0 & 66 & 80 & \multirow[t]{4}{*}{0.001} \\
\hline $1^{\text {st }}$ month & 10 & 4 & 0 & 66 & 80 & \\
\hline $6^{\text {th }}$ month & 8 & 3 & 0 & 69 & 80 & \\
\hline $10^{\text {th }}$ month & 2 & 0 & 0 & 78 & 80 & \\
\hline \multicolumn{7}{|c|}{ Experience of redness and skin eruptions on hands } \\
\hline Baseline & 0 & 0 & 0 & 80 & 80 & \multirow[t]{4}{*}{0.001} \\
\hline $1^{\text {st }}$ month & 6 & 3 & 0 & 71 & 80 & \\
\hline $6^{\text {th }}$ month & 3 & 1 & 0 & 76 & 80 & \\
\hline $10^{\text {th }}$ month & 0 & 0 & 0 & 80 & 80 & \\
\hline
\end{tabular}

The absolute eosinophil count at the beginning and end of academic year is shown in Table No 2. A statistically rise in the mean absolute eosinophil count can be observed after exposure.

Table 2: Rise in absolute eosinophil count

\begin{tabular}{|l|c|c|c|c|}
\hline $\begin{array}{c}\text { Time of } \\
\text { recording }\end{array}$ & Mean & Standard deviation & $\begin{array}{c}\text { Standard error } \\
\text { of mean }\end{array}$ & P-value \\
\hline Baseline & 53.22 & 61.15 & 6.84 & $\mathbf{0 . 0 0 0}$ \\
\hline After exposure & 92.66 & 82.24 & 9.20 & \\
\hline
\end{tabular}

\section{Discussion}

The general picture revealed in the present study was that skin symptoms persist for some time and show a declining trend from around the $6^{\text {th }}$ month onwards. It was accompanied by a rise in eosinophils circulating in blood. Symptoms of chemical irritation of skin have also been reported in various studies evaluating the physical reactions developing after exposure to formalin. In the present study, $17.5 \%$ of the participants experienced itching after their first exposure. Takshi et al ${ }^{10}$ Kundu S \& Gangrade $\mathrm{P},{ }^{11}$ Elshaer NSM et $\mathrm{al}^{12}$ and Oniyje FM et $\mathrm{al}^{13}$ have reported itching in $25.53 \%, 36.6 \%$ and $44 \%$ of students respectively. Koirala S et $\mathrm{al}^{14}$ have reported an incidence of as high as $82.3 \%$ after the first exposure. Lower occurrence of this symptom was observed by Yadav A et al ${ }^{15}$ and Emue BE et al. ${ }^{16}$ With regard to the other skin symptoms in our study no occurence of skin changes like redness, eruptions, peeling, etc was observed on first exposure. But after one month of exposure, $11.25 \%$ of students developed some type of skin changes, which then declined gradually over the remaining part of the study period. Our figures are in consonance with Hemalatha NR et $\mathrm{al}^{17}(11.3 \%)$ of students, Kundu S \& Gangrade $\mathrm{P}^{11}(10.64 \%)$ and Jain SR et $\mathrm{al}^{18}(10.8 \%)$. Koirala $\mathrm{S}$ et $\mathrm{al}^{14}$ have reported in their study that $93 \%$ of the students develop skin rashes after exposure. Emue BE et $\mathrm{al}^{16}$ and Elshaer NSM et $\mathrm{al}^{12}$ in their works have observed that skin problems increased with repeated exposure.

The various dermatological symptoms could be a manifestation of contact dermatitis in the affected students. Formaldehyde-induced contact dermatitis could be both of irritant as well as allergic pathology. The irritant property of formaldehyde is well known. But, formaldehyde can also act as a local allergen. ${ }^{2,3}$ It is a known primary skin sensitizing agent which is believed to cause a Type IV hypersensitivity reaction that manifests as itching and contact dermatitis. ${ }^{19}$ There might be an additional role of IgE-mediated hypersensitivity, but there is no clear consensus on this mechanism. ${ }^{5,20}$ But, studies do show that there is a tendency of positive correlation between formaldehyde exposure and atopic eczema. ${ }^{21}$ So, its possibility cannot be absolutely ruled out. Allergic contact dermatitis from formaldehyde has been reported in numerous studies. ${ }^{19,22,23}$ Some studies have also revealed that formaldehyde has a property of forming vesicles by causing certain changes at the level of the plasma membrane of cells. ${ }^{24,25}$ Kundu $\mathrm{S} \&$ Gangrade $\mathrm{P}^{11}$ have suggested that formaldehyde causes necrosis and degeneration in the epithelial layers. Thus, there are multiple ways by which formaldehyde affects the skin which explain 
the occurrence of the symptoms in our study. However, the present study also indicates that over time the body acclimatizes to its effect.

Both allergic dermatitis and chemical hypersensitivity cause an increase in eosinophils of blood. ${ }^{26,27}$ Increase in number of circulating eosinophils was also observed in similar studies in occupationally exposed groups. ${ }^{28}$ The sensitizing effect of formaldehyde was demonstrated in an animal-model study, where the authors noted a significantly raised eosinophil count in the blood samples of sensitized guinea-pigs. $^{29}$ All these factors underline the role of formaldehyde in raising the eosinophil count of exposed subjects.

\section{Conclusion}

The occurence of various skin symptoms and a concomitant rise in eosinophils point towards the role of formaldehyde in inciting an allergic inflammation in the body. We should therefore institute steps to reduce dermal contact to this chemical by use of protective gloves. Apart from this simple step, methods of overall reduction of exposure like improving ventilation across the dissection hall, use of accessory chemicals and alternative embalming fluids should also be promoted. This would reduce the burden of occupational detriment and preserve proficiency of medical students in the long run.

\section{Conflict of Interest: Nil.}

\section{References}

1. Raja SD, Sultana B. Potential Health Hazards for Students Exposed to Formaldehyde in the Gross Anatomy Laboratory. $J$ Environ Health. 2012;74(6):36-40.

2. Binawara BK, Rajnee, Choudhary S, Mathur KC, Sharma H, Goyal K. Acute Effect of Formalin on Pulmonary Function Tests in Medical Students. Pak J Physiol. 2010;6(2):8.

3. Hauptmann M, Stewart PA, Lubin JH, Beane Freeman LE, Hornung RW, Herrick RF, Hoover RN, Fraumeni JF, Blair A, Hayes RB. Mortality from lymphohematopoietic malignancies and brain cancer among embalmers exposed to formaldehyde. J Natl Cancer Inst. 2009;101(24):1696-1708.

4. International Agency for Research on Cancer. Formaldehyde. IARC Monographs on the Evaluation of the Carcinogenic Risk of Chemicals to Humans. 2006;88:39-325.

5. Agency for Toxic Substances and Disease Registry. Formaldehyde. Addendum to the toxicological profile for Formaldehyde. Atlanta: Division of Toxicology and Environmental Medicine. 2010;2-54.

6. Zhang L, Tang X, Rothman N, Vermeulen R, Ji Z, Shen M. et al. Occupational Exposure to Formaldehyde, Hematotoxicity and Leukemia-Specific Chromosome Changes in Cultured Myeloid Progenitor Cells. Cancer Epidemiol Biomarkers Prev. 2010;19(1):80-88.

7. Ihentuge C, Ugochukwu C. Evaluation of role of dissection in medical education. A case study of Imo state university, Nigeria. The Faseb J. 2015;29(1):548.554.

8. Pal GK, Pal P. Textbook of Practical Physiology. $3^{\text {rd }}$ ed. Universities Press; 2013.

9. Ghai CL. A Textbook of Practical Physiology. $8^{\text {th }}$ ed. Jaypee Brothers Medical Publishers; 2013.

10. Takahashi S, Tsuji K, Fujii K, Okazaki F, Takigawa T, Ohtsuka A, et al. Prospective study of clinical symptoms and skin test reactions in medical students exposed to formaldehyde gas. J Dermatol. 2007;34(5):283-289.

11. Kundu S, Gangrade P. Study of the toxic effects of formaldehyde vapours within dissection hall on the first year Indian medical students. Int J Anat Res. 2015;3(2):1179-1190.

12. Elshaer N.S.M., Mahmoud M.A.E. Toxic effects of formalintreated cadaver on medical students, staff members, and workers in the Alexandria Faculty of Medicine. Alex J Med. 2017;1-7.

13. Onyije FM, Avwioro OG. Excruciating effects of formaldehyde exposure to students in gross anatomy dissection laboratory. The International J Occup Environ Med. 2012;3:92-95.

14. Koirala S, Shah S, Khanal L, Pokhrel C, Poudel D. Effect of Formalin among the medical and dental students attending regular laboratory session in dissecting hall, in Department of Human Anatomy, in B.P. Koirala Institute of Health Sciences. Eur J Forensic Sci. 2015;2(2):1-4.

15. Yadav A, Yadav M. A Study of the Effects of Formalin on First Year MBBS Students. Sch J App Med Sci. 2014;2(5B):1588-1590.

16. Emue BE, Ayanniyi AA, Nwegbu MM, Ibekwe TS. Acute Effects of Formalin-Treated Cadaver on Nigerian Medical Students. Am J Trop Med Public Health. 2011;(3):89-96.

17. Hemalatha NR, Mamatha PS. Acute symptoms experienced by Medical Students on first exposure to Formalin in dissection hall. Int J Sci Res Educ. 2015;3(4):3205-3209.

18. Jain SR, Nahar PS, Baig MM. Study of Formalin Toxicity in I MBBS Students. Int J Sci Res. 2012;1(3):233-235.

19. Lyapina M, Kisselova-Yaneva A, Krasteva A, TzekovaYaneva M, Dencheva-Garova M. Allergic contact dermatitis from formaldehyde exposure. $J$ of IMAB. 2012;18(4):255-262.

20. World Health Organization. Formaldehyde. Air quality guidelines ( $2^{\text {nd }}$ edition) $2001 ; 4-5$.

21. Matsunaga I, Miyake Y, Yoshida T. Ambient formaldehyde levels and allergic disorders among Japanese pregnant women: Baseline data from the Osaka maternal and child health study. Ann Epidemiol. 2008;18(1):78-84.

22. Owen CM, Beck MH. Occupational allergic contact dermatitis from phenol-formaldehyde resins. Contact Dermatitis. 2001;45:294-5.

23. Mathur N, Rastogi SK. Respiratory effects due to occupational exposure to formaldehyde: Systematic review with meta-analysis. Indian J Occup Environ Med. 2007;11(1):2631.

24. Fox HC, Johnson FB, Whiting J, Roller PP. Formaldehyde Fixation. J Histochem Cytochem. 1985;33(8):845-853.

25. Scott RE: Plasma membrane vesiculation: a new technique for isolation of plasma membranes. Sci. 1976;194:743

26. Hoffbrand AV, Catovsky D, Tuddenham EGD. Postgraduate Haematology. Blackwell Publishing. $5^{\text {th }}$ edition 2005:294-295.

27. Lichtman AM, Beutler E, Seligsohn U, Kaushansky K, Kipps TO. Williams Hematology: Eosinophils and their disorders. McGraw Hill Medical. $7^{\text {th }}$ edition.

28. Norback D. Indoor air pollutant in school: Nasal patency and biomarkers in nasal lavage. Allergy. 2000;55:163-170.

29. Kiec-Swierczynska M, Krecisz B, Krysiak B. Kuchowicz E, Rydzynski K. Occupational allergy to aldehydes in healthcare workers. Clinical observations. Experiments. Int J Occup Med Environ Health. 1998;11(4):349-358.

How to cite this article: Dhar D.K, Chaudhuri S, Singh S.K, Bhattacharya S. Effect of exposure to formaldehyde on the skin of first-year medical students during Anatomy dissection: A longitudinal study J Community Health Manag. 2018;5(4):202-204. 